\title{
Strategies to promote the Inclusion of People with Visual Disabilities in the Technological Institute of Villahermosa
}

\section{Estrategias para propiciar la Inclusión de Personas con Discapacidad Visual en el Instituto Tecnológico de Villahermosa}

OLÁN-SÁNCHEZ, María Dolores †๋, LOPEZ-VALDIVIESO, Leticia*, MARTÍNEZ-VICHEL, Guadalupe and PRIEGO-GÓMEZ, María Candelaria

Tecnológico Nacional de México/Instituto Tecnológico de Villahermosa

ID $1^{\text {st }}$ Author: María Dolores, Olán-Sánchez / ORC ID: 0000-0003-2082-2776, Researcher ID Thomson: ABC.2971-2020, CVU CONACYT ID: 1093090

ID $1{ }^{\text {st }}$ Coauthor: Leticia, López-Valdivieso / ORC ID: 0000-0001-6288-3636, Researcher ID Thomson: G-5753-2018, CVU CONACYT ID: 67839

ID $2^{\text {nd }}$ Coauthor: Guadalupe, Martínez-Vichel / ORC ID: 0000-0001-5121-6141, Researcher ID Thomson: G-5753-2018, CVU CONACYT ID: 67839

ID $3^{\text {rd }}$ Coauthor: María Candelaria, Priego-Gómez / ORC ID: 0000-0003-1037-1326, Researcher ID Thomson: ABC-30172020, CVU CONACYT ID: 1093099

DOI: $10.35429 /$ EJROP.2020.10.6.21.27

Received April 18, 2020; Accepted June 30, 2020

\section{Abstract}

The objective of this article is to show the actions generated in the initial educational program of the Technological Institute of Villahermosa for the inclusion of persons with visual disabilities, from which mechanisms for improvement were established in a positive way with a view to becoming an inclusive institution. Interest in people with special educational needs for a bachelor's degree is growing; in Tabasco State, there are higher middle-level institutions working for inclusion. Therefore, it is necessary to create opportunities for improvement not only in the curricula and programs of study, but also to make the actors become aware, trained and takes action to meet this demand. To involve competent authorities of the needs required in infrastructure, training, furniture and various adaptations that involve the teaching-learning process. Some of these necessities were identified in the Institute through the routes and surveys carried out on the basis of the Standards for the Accessibility of Persons with Disabilities.

Inclusion, Disability, Opportunity

\section{Resumen}

El objetivo del presente artículo es mostrar las acciones generadas en el programa inicial de educación del Instituto Tecnológico de Villahermosa para la inclusión de personas con discapacidad visual, a partir de las cuales, se establecieron mecanismos de mejora de forma propositiva con miras a constituirnos como una institución inclusiva. El interés en personas con necesidades educativas especiales por cursar una carrera de licenciatura está creciendo; en el estado de Tabasco, hay instituciones de nivel medio superior que están trabajando en favor de la inclusión. Por tanto, es necesario crear oportunidades de mejora no sólo en los planes y programas de estudio, sino también lograr que los actores se concienticen, se capaciten y tomen acciones para afrontar esta demanda. Hacer partícipes a las autoridades competentes de las necesidades que se requieren en infraestructura, capacitación, mobiliario y adecuaciones diversas que involucra el proceso de enseñanza-aprendizaje. Parte de estas necesidades se identificaron en el Instituto mediante los recorridos y levantamientos realizados con fundamento en las Normas para la Accesibilidad de las Personas con Discapacidad.

Inclusión, Discapacidad, Oportunidad

Citation OLÁN-SÁNCHEZ, María Dolores, LOPEZ-VALDIVIESO, Leticia, MARTÍNEZ-VICHEL, Guadalupe and PRIEGO-GÓMEZ, María Candelaria. Strategies to promote the Inclusion of People with Visual Disabilities in the Technological Institute of Villahermosa. ECORFAN Journal-Republic of Paraguay. 2020. 6-10: 21-27

\footnotetext{
* Correspondence to Author (email: leticia.lv@villahermosa.tecnm.mx)

$\dagger$ Researcher contributing as first author.
} 


\section{Introduction}

Different ways have been developed to conceptualize disability, one of the aspects involves a model of medical science and the other considers the social aspect. As a medical model, a diagnosis is assumed with a treatment aimed at a better adaptation of the person and a change in behavior. On the other hand, the social model of disability considers the phenomenon mainly as a "social" problem, from the point of view of the integration of people with disabilities into society.

The concept evolves as a result of the interaction between people with disabilities as well as the barriers they face, due to the attitude of others and the environment that prevent their full and effective participation in society, on an equal basis with others. This has allowed us to move from a pejorative definition of disability to a more humane definition of disability. Currently we can identify different disabilities, for example: physical, intellectual, mental, psychosocial, multiple, sensory (hearing, visual), among others. In 1983 the WHO defined 'disability' as "any restriction or absence (due to an impairment), of the ability to perform an activity in the manner or within the range considered normal for a human being" (WHO, 1983: 56).

Disability is not an attribute of the person, but a complicated set of conditions, many of which are created by the social environment. Therefore, managing the problem requires social action and it is society's collective responsibility to make the necessary modifications for the full participation of persons with disabilities in all areas of social life. The issue is, therefore, at the level of attitudes and ideology, and requires social changes, which are transformed at the political level into a human rights issue. The search for mechanisms that undertake a change in the structures of academic training with an inclusive model is a topic of interest incorporated in the Integral Educational Models. The educational institutions must work to create the ideal space that offers not only stability and security to people with disabilities, but also something broader and deeper that affects not only the physical adjustments, since radical change involves commitment, dedication and responsibility, all in all, seen as an opportunity to improve the socio-economic development of the country.
A society must attend to the needs of the disabled population, and not vice versa, that disabled people are integrated into our environment. The first thing is inclusion, the second is integration. The figure of the teacher plays an important role in inclusion, he or she should not only be a knowledge manager, that is, not only should he or she be involved in the classroom, he or she should also be a researcher, a leader who promotes the solution to the problems experienced in schools. This will allow him to be sensitive and empathize with the needs of students.

This is how being inclusive will be achieved. You cannot be inclusive from the oral, from the speech. It is necessary to really get involved in the multiple realities that the Others bring with them. Building an inclusive classroom requires that the teacher be willing to act positively in favor of this. This also involves his or her peers, parents, and even the students themselves. Working alone on this issue wears out the will, as inclusion is a process, not an overnight change. In this regard, UNESCO (2020) states: "Inclusion... is a process: measures and practices that embrace diversity and create a sense of belonging, based on the conviction that each person has value and potential and must be respected. [...]" (p.11). It should be thought that if learning communities are formed, where winwin is the condition, students learn, but also teachers. "Careful planning and the provision of inclusive education can lead to improvements in academic performance, social and emotional development, self-esteem, and peer acceptance. (UNESCO, 2020, P.18)".

We recognize the benefits of inclusive education for human development. In this way our institution contributes to the eradication of discrimination and stigmatization of people in our classrooms. On the other hand, the support currently provided by technological development to the student community with special educational needs is immeasurable; it has allowed many young people to have access to education at any level; the various technical innovations have reduced the gap between the vulnerable population and the educational institutions. However, there are still countries and/or cities that do not have the economic and, therefore, technological resources to be able to receive their visitors or users with some kind of disability, in their own facilities according to their conditions.

OLÁN-SÁNCHEZ, María Dolores, LOPEZ-VALDIVIESO, Leticia, MARTÍNEZ-VICHEL, Guadalupe and PRIEGO-GÓMEZ, María Candelaria. Strategies to promote the Inclusion of People with Visual Disabilities in the Technological Institute of Villahermosa. ECORFAN Journal-Republic of Paraguay 
Hence the importance of opening various activities that allow our students and future professionals, not only to be trained but also to be aware of the needs that people with disabilities live and that together we can, from interdisciplinary work, create favorable actions with a view to constitute ourselves as an inclusive technology.

For all these reasons, we have set ourselves the following questions to guide our work in the field. What kind of actions are necessary to undertake to constitute ourselves as an inclusive Institute? How suitable is the design of the physical infrastructure and furniture of the Institute?

\section{Metodología}

In order to develop the actions contemplated in the initial plan for inclusive education, the first stage was carried out in the field. Raising information in situ by means of the physical tour, with the purpose of directly observing the characteristics and conditions of the institute's infrastructure. Likewise, determining if the construction was aligned with the Manual of Technical Standards of Accessibility and the precepts of the General Law for the Inclusion of Persons with Disabilities, specifically for blind people. In the second stage, objects and/or artifacts were identified that would serve as support or satisfaction for the blind. This search provided the basis for the creation of prototypes ad hoc to the needs of the institute.

Likewise, the bibliographic research that was carried out on the needs of blind people, allowed to concentrate data and information to design relevant proposals strengthened in a conceptual theoretical framework proper of a formal research.

It is worth mentioning that the methodological design to carry out the diagnosis of the current situation regarding the problems under study, was focused on the realization of the following activities:

I. Detection of the problem.

II. Description of the scenario, to identify the current conditions of the facilities.

III. Strategic planning of the improvement actions to be implemented.
IV. Delivery of results to promote the development of strategies in the teaching, student and administrative community.

The methodological proposal that was developed allowed to give way to the proposal of the ITVH Initial Education Program for the Inclusion of People with Visual Disabilities, and considered the design, development and dissemination of the following products:

a. The key routes or walkways for orientation and access to the buildings

b. Supporting signs to identify the buildings.

c. Awareness posters on how to help blind people

d. Design and printing of information leaflet

\section{Diagnosis of current conditions}

The Tecnológico Nacional de México Villahermosa campus is located at km.3.5 of the Villahermosa-Frontera highway, in the state of Tabasco. It currently has 31 buildings, most of which are two-storey. A population of approximately 5000 people, made up of teaching, administrative, support and assistance personnel and students; the latter represent approximately $88 \%$ of the aforementioned population.

In order to understand the problems that are presented in the Institute, the following are listed in Table 1, the aspects found in the physical infrastructure and furniture and the state they keep with respect to the recommendations indicated by the Technical Standards Manual for Accessibility of People with Disabilities; these data were collected through an observation card, documented with photographs: 


\begin{tabular}{|l|l|l|}
\hline \multicolumn{1}{|c|}{ What you have } & \multicolumn{2}{c|}{$\begin{array}{c}\text { Complies } \\
\text { with the } \\
\text { Yes }\end{array}$} \\
\hline $\begin{array}{l}\text { Access ramps (without signs, } \\
\text { dimensions, painting and proper } \\
\text { angle of inclination) }\end{array}$ & & $\mathrm{X}$ \\
\hline $\begin{array}{l}\text { Toilets (With adapted for people with } \\
\text { wheelchairs) }\end{array}$ & $\mathrm{X}$ & \\
\hline $\begin{array}{l}\text { Toilets and sinks for people with } \\
\text { dwarfism }\end{array}$ & $\mathrm{X}$ & \\
\hline $\begin{array}{l}\text { Sound system with speakers for } \\
\text { broadcasting }\end{array}$ & $\mathrm{X}$ & \\
\hline Elevator in a building. & $\mathrm{X}$ & \\
\hline Hands on some buildings. & $\mathrm{X}$ & $\mathrm{X}$ \\
\hline Furniture for left-handed people. & $\mathrm{X}$ & \\
\hline Psychological care area. & N.A. & \\
\hline Institutional plan for tutoring. & N.A. & \\
\hline $\begin{array}{l}\text { Promotion of the teaching of Mexican } \\
\text { Sign Language. }\end{array}$ & & \\
\hline
\end{tabular}

Table 1 Diagnosis of spaces and programs for the care of visually impaired people. (N.A.= Not applicable) Source: Project Collaboration Team. 2019

Once the opportunities to improve the physical spaces were detected, the problem of improving the common spaces for the care of visually impaired people was addressed in a strict sense. One of the many obstacles that visually impaired people have to overcome is the access to the buildings on campus. This includes stairs without signs; very narrow entrances in some rooms and doors with a hydraulic arm; corridors with broken floors; bathrooms that mostly do not contemplate the technical specifications established to make them accessible and appropriate for people with disabilities; among others. The multidisciplinary team that participated in the proposal made a relevant strategic planning of improvement actions to be implemented, these proposals were presented to the ITVH authorities as an impulse to benefit the students who require it.

\section{Results}

As an implementation proposal for the inclusion of visually impaired people in the study context, the following strategies are proposed:

a. To design diverse prototypes, that serve as support for the blind users or visitors, considering the decrees established in the Manual of Technical Norms of Accessibility for People with Disabilities. b. Disseminate in various academic forums and the website of the Technological Institute of Villahermosa, the benefits of the program, and present the prototypes

c. The Information Center is considered the model for the implementation of the prototypes, so the signaling prototypes for the location and orientation must be initiated and placed from the different accesses to this place.

d. Elaboration of posters with the Braille System, so that blind people have data or information that allows them to locate themselves in space.

e. Complementary activities aimed at raising awareness among students for the integration of people with disabilities.

The prototypes that were designed as part of the Initial Education Program for the Inclusion of People with Disabilities are an important development for the Technological Institute, since it means advancing in the social inclusion of the vulnerable population, whether they are students or any occasional transit person. The important thing is to start providing the necessary conditions so that they can access the campus. It is intended that the proposal will impact and even eliminate the architectural barrier presented by the standard designs of technical accessibility.

\section{Contributions of the deliverables}

Based on an analysis of the proposed implementations and the impact as an opportunity for improvement, the aspects of functionality and degree of innovation of each of the contributions made are detailed.

a. Key routes or walkways for orientation and access to buildings. This consists of placing a standard guide for the visually impaired on the pavement of the walkers, allowing blind people to walk and move around all the areas they require. All according to the measures and specifications that mark the Manual of Technical Norms of Accessibility.

b. Support signs, to identify the buildings, made of adhesive vinyl or acrylic. Indicating the name of the area or place. The legend must be written in Spanish and in Braille. Likewise, they are adequate to the measures and specifications that mark the Technical Standards Manual of Accessibility.

OLÁN-SÁNCHEZ, María Dolores, LOPEZ-VALDIVIESO, Leticia, MARTÍNEZ-VICHEL, Guadalupe and PRIEGO-GÓMEZ, María Candelaria. Strategies to promote the Inclusion of People with Visual Disabilities in the Technological Institute of Villahermosa. ECORFAN Journal-Republic of Paraguay 
c. Awareness posters, on How does it help blind people? This consists of placing in a visible way information for the users or visitors of the Information Center, on how we should correspond to the needs of a blind person. They are also made of adhesive vinyl or acrylic, so that their quality is durable.

d. Inclusive Education Day, whose main objective was to disseminate the program of inclusive education through life experiences that motivate positive actions in the educational and social environment in favor of the integration of people with disabilities.

The following are some advantages and disadvantages of the key routes model proposed for installation within the institution:

\begin{tabular}{|c|c|}
\hline & \\
\hline $\begin{array}{l}\text { As an inclusive and } \\
\text { integral institute, it } \\
\text { contributes to the } \\
\text { implementation of a } \\
\text { support system for all } \\
\text { visually impaired people, } \\
\text { giving ITVH a better } \\
\text { position in terms of its } \\
\text { quality and inclusion } \\
\text { system. }\end{array}$ & $\begin{array}{l}\text { Approval of a budget } \\
\text { is required for the } \\
\text { purchase of materials } \\
\text { needed to implement } \\
\text { throughout the } \\
\text { technology. }\end{array}$ \\
\hline $\begin{array}{l}\text { It is proposed that the } \\
\text { design and elaboration be } \\
\text { done by ITVH students } \\
\text { themselves, contributing } \\
\text { significantly to the } \\
\text { reduction of labor costs. }\end{array}$ & $\begin{array}{l}\text { As they are carried } \\
\text { out by ITVH students } \\
\text { themselves, there is a } \\
\text { risk that the deadlines } \\
\text { for their execution } \\
\text { will be extended. }\end{array}$ \\
\hline $\begin{array}{l}\text { As it is made of slabs, } \\
\text { which can be fixed to the } \\
\text { floor, its installation is } \\
\text { easier without having to } \\
\text { modify all the spaces. }\end{array}$ & $\begin{array}{l}\text { In order for the } \\
\text { project to move } \\
\text { forward, there is a } \\
\text { need for students and } \\
\text { support staff to help } \\
\text { with the labor. }\end{array}$ \\
\hline $\begin{array}{l}\text { The slabs are made to be } \\
\text { installed indoors and } \\
\text { outdoors which supports } \\
\text { rain, sun and air factors. }\end{array}$ & $\begin{array}{l}\text { The use of epoxy } \\
\text { luminescent paints } \\
\text { would increase the } \\
\text { project cost due to its } \\
\text { high market price. }\end{array}$ \\
\hline $\begin{array}{l}\text { The use of plastic cuttings } \\
\text { replaces engraving, } \\
\text { which decreases its cost, } \\
\text { material use, and } \\
\text { sustainability by reusing } \\
\text { polluting materials. }\end{array}$ & $\begin{array}{l}\text { It takes at least } 15 \\
\text { days to make a fully } \\
\text { finished slab, which } \\
\text { requires a good } \\
\text { number of students } \\
\text { (labor) to have more } \\
\text { slabs prepared. }\end{array}$ \\
\hline
\end{tabular}

Table 2 Advantages and disadvantages of the prototype of key routes proposed for the ITVH

Source: Project Collaboration Team. 2019
The details of the models of: prototype of key routes, support signs, awareness posters and inclusive education day, allowed to generate evidence of the deliverables that were made to the authorities of the Technological Institute of Villahermosa.

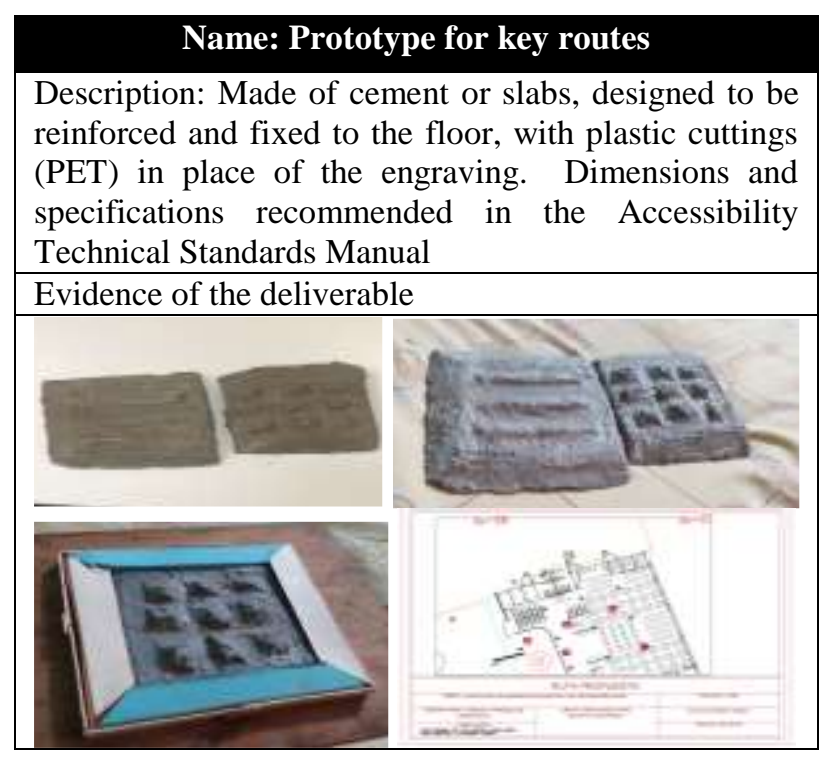

Table 3 Characterization of the prototype of the key routes proposed for the ITVH, for the inclusion of visually impaired people

Source: Collaboration team of the project. 2019

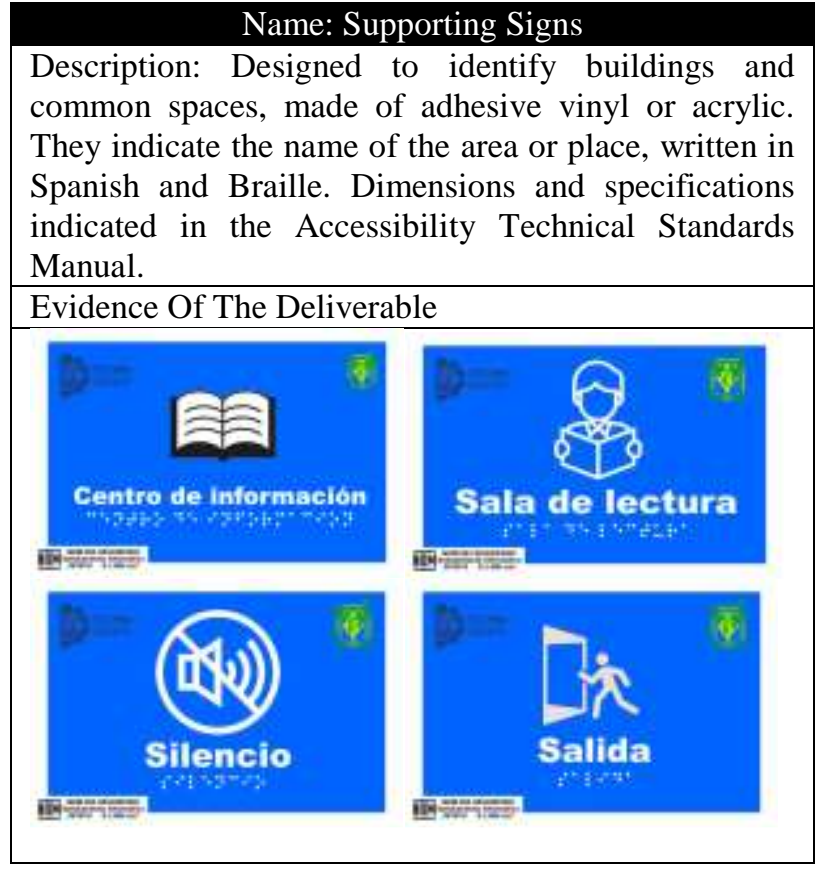

Table 4 Characterization of the support signs proposed for the ITVH, for the inclusion of visually impaired people Source: Collaboration team of the project. 2019 


\section{Name: Awareness Posters}

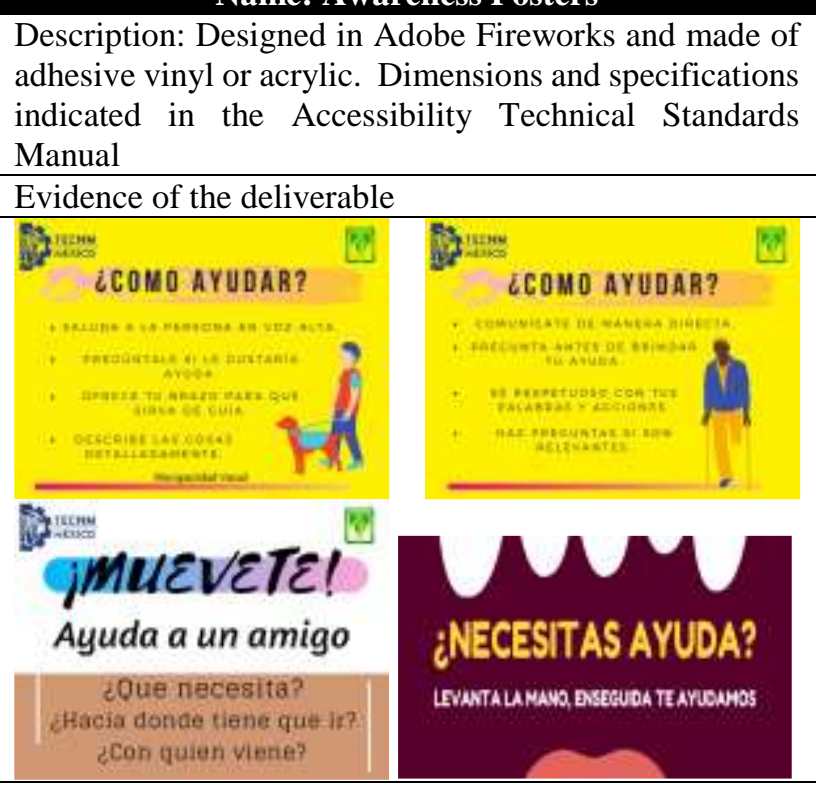

Table 5 Characterization of the awareness posters proposed for the ITVH, for the inclusion of visually impaired people

Source: Collaboration team of the project. 2019

From a social aspect, this proposal will be equally useful to continue offering a quality educational service safeguarding integrity by building a path type gap for people with visual impairment and signs written in Braille

\section{Conclusions}

In view of the questions raised at the beginning of this document regarding the actions and suitability of the infrastructure of the institute, it can be concluded that actions such as those to promote an inclusive education in the institutions, implies a change of philosophy in education, which makes it possible to understand that all students have the right to the opportunity to be trained in the professional field and be part of the intellectual capital with the same opportunities for growth, development and competitiveness.

As part of the actions aimed at an inclusive educational institution, it should open the way to awareness, not only from the curricular plan, but from the educational services it provides, considering of vital importance the architectural accessibility, because it depends on it to generate security and independence to people with visual impairment.
In this sense, we consider that there are many opportunities for improvement. While we recognize the progress in the construction of ramps, a building with an elevator, bathrooms and classrooms with ideal characteristics to serve people with disabilities, there are more buildings with a conventional construction. The aspect of architectural accessibility is not only the ramps, but also the conditions in which the floors are, the drains (without grids or deteriorated) to avoid falls due to flooding or muddy parts, the signaling of buildings and safe paths for daily traffic, are part of the common space for visitors and blind and visually impaired users.

Above all, for the visually impaired, being in a different place, with unknown dimensions and orientation generates anxiety and insecurity, as they become familiar with the site; the signage provides valuable information for the integrity of the person and elements such as signs in Braille and writing system, will facilitate their movement and displacement outside and inside buildings, providing a reliable and friendly environment. One of the contributions of this project are the tactile pruning slabs for the creation of the key routes or walkways for orientation and access to the buildings.

These are placed in reflective yellow, can be assembled and fixed to the ground, and their installation is easier without the need to modify all the spaces; these slabs are made to be installed indoors and outdoors, which withstand rain, sun and air factors. They are also environmentally friendly, because plastic cuttings are used instead of engraving, which reduces their cost and contributes to sustainability by reusing polluting materials.

Therefore, it is feasible to make adjustments, using other resources that allow us to provide our educational service considering the diversity.

We hope that ITVH will allow us to give continuity to the actions aimed at the inclusion of people with disabilities, and that this project will go beyond our school. 


\section{References}

Aquino Zúñiga, Silvia P., García Martínez, Verónica e Izquierdo, Jesús. (2012) La inclusión educativa de ciegos y baja visión en el nivel superior. Un estudio de caso. Sinéctica No. 39.

Cámara de Diputados del H. Congreso de la Unión. (2018). Ley General para la inclusión de las personas con Discapacidad. Últimas reformas DOF 12-07-2018.

De La Cruz Villegas, Verónica, Zúñiga Rodríguez, Maricela y Aquino Zúñiga, Silvia P. (2013) Estado del conocimiento de la discapacidad visual en el contexto educativo: Experiencias en su construcción. Edähi, Boletín Científico de Ciencias Sociales y Humanidades del ICSHU. Vol. 2 No. 3.

Instituto Nacional de la Infraestructura Física Educativa. (2011). Normas y Especificaciones para estudios, proyectos, construcción e instalaciones. Norma de accesibilidad. Volumen 3 Habilidad y funcionamiento, Tomo 2.

Oganización de las Naciones Unidas para la Educación, la Ciencia y la Cultura. (2020). Informe de Seguimiento de la Educación en el Mundo 2020. UNESCO. Paris: UNESCO.

Organización Mundial de la Salud. Clasificación Internacional del Funcionamiento, de la Discapacidad y de la Salud (CIDDM-2). Grupo de Clasificación, Evaluación, Encuestas y Terminología. Ginebra, Suiza.

Pegalajar, M. (2012). Tiflotecnología e inclusión educativa: evaluación de sus posibilidades didácticas para el alumnado con discapacidad visual. Recuperado de: http://www.ujaen.es/revista/reid/revista/n9/REI D9art1.pdf 